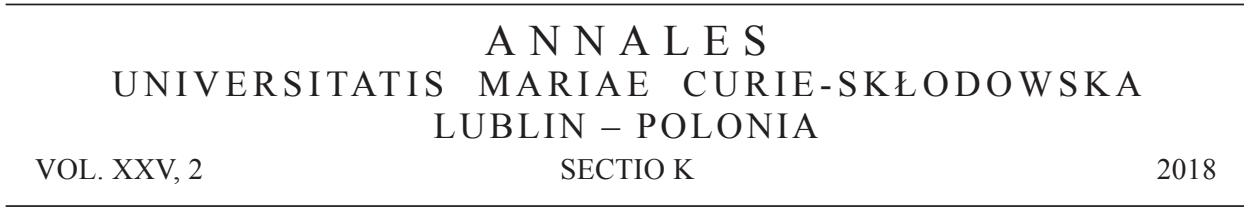

Jagiellonian University in Kraków. Faculty of International and Political Studies

\author{
MAGDALENA CYRAN
}

ORCID ID: https://orcid.org/0000-0001-8645-3681

\title{
Radicalization of Public Sentiment in Sikh Society after 1947
}

\begin{abstract}
In founding a new religious denomination - Sikhism - Guru Nanak in a way combines two rival religions - Hinduism and Islam. The tolerant nature of Sikhism garnered him many proponents, which contributed to the establishment of the Sikh Empire in the $19^{\text {th }}$ century. The Empire flourished until it was overthrown by armed forces of the British Crown. After the departure of the British colonizers in 1947, the idea of creating a sovereign Sikh state called Khalistān arose in the Punjab - the cradle of Sikhism in India. Gradually, the sentiments of large portion of the Sikh population became radicalized. A terrorist organization, formed by the Sikh fundamentalist Jarnail Singh Bhindranwale and supported by many Sikhs, began persecuting the followers of other religions and fighting for the creation of a Sikh state in Punjab. The radicalization of public sentiments among the Sikh population led to mass pogroms, a military operation in the Sikhs' holy place and the assassination of Indira Gandhi, the prime minister of India.
\end{abstract}

Key words: Sikhism, India, fundamentalism, separatism

\section{INTRODUCTION}

The division of British India in 1947 had a very strong impact on the area of the Punjab, which was located in the north-east of the colony. Although it is mostly inhabited by Muslims and Hindus, the Sikhs are one of the most important religious groups in the area. Sikhism was founded in the $15^{\text {th }}$ century by Guru Nanak, who, living in a time of conflict between the followers of Islam and Hinduism, decided to create a religion that would unite elements of both religions.

The aim of the article is to analyze the events that led to the intensification of radical tendencies among the Sikh community in India and to evaluate which factors 
had the greatest influence on the changes in attitudes among the members of this religious group. Particular attention will be paid to the activities of the central government of India in cooperating with the Sikh community and finding compromise solutions, as well as to actions by decision-makers to calm down the mood in the Punjab and to combat terrorist groups.

\section{DEVELOPMENT OF SIKHISM IN INDIA}

Sikhism, like Islam, is a monotheistic religion [Igielski 2008: 66-68], in which god is an abstract and is not represented in art, unlike Hinduism, where images of gods are known and can be seen in temples, in films and even in fairy tales. In turn, Sikhism draws from Hindu views on such issues as the problem of sin, the idea of reincarnation, as well as some holidays. Unlike Hinduism, the liberation from the cycle of subsequent incarnations does not, however, come from sacrifice or rituals, but from thinking about god, living in harmony with the teachings of the guru and doing work in the service of others [Cole, Sambhi 1987: 8]. Pillars of Sikhism include praying to god by saying his name, working honestly in the service of other members of the community and sharing one's possessions [Igielski 2008: 62-65]. To this day, at every gurdwara (a Sikh temple), there is a generally accessible eatery where everyone, regardless of their religion or origin, can eat a free meal. Within the Sikh temples there are often places where people can spend the night for free, which is used by many pilgrims who come to holy places. Another vital change which Sikhism introduced to everyday life of its adherents was the so-called "dignity of work". This principle is based on the assumption that work is worth every effort, including physical effort. According to traditional Indian thinking, any work requiring physical effort is unsuitable for people born in high castes and can only be done by low-born people. In Sikhism, physical work is considered to be a means of bringing people closer to god. A very strong emphasis was placed in Sikhism on tolerance towards other religions [Igielski 2008: 62-65]. The persecution suffered by the Sikh community at the hands of the Islamic rulers who held power in the Indian Peninsula has strongly influenced the Sikh perception of other religions.

For the twenty-five years of the existence of Sikhism, the main figure in the Sikh community was the so-called guru, the successor of the founder of religion, who cared for the strengthening of the religion and was a kind of enlightened teacher, leading Sikhs to the knowledge of god [Igielski 2008: 9]. Ten gurus have appeared in the history of Sikhism. Each of them chose their own successor. Over time, the gurus have risen to the rank of saints. Gobind Singh, the tenth guru, played a very important role in building a sense of separate identity among the Sikhs. He introduced five symbols that distinguish Sikhs from followers of other religions, including the characteristic turban that covers the long hair of every Sikh, as well as the dagger. In addition, he established a military order, Khalsa, to defend the followers of Guru 
Nanak against Muslim invaders. It was the beginning of military traditions in the Sikh community, which today characterize this religious minority [Igielski 2008: 89]. The changes introduced by Gobind Singh reinforced the sense of separateness of the Sikhs and allowed for quick identification of their fellow believers, as well as strengthened the division into "us and them". Moreover, before Guru Gobind Singh died, he appointed as his successor a collection of texts collected by previous gurus, i.e. the Holy Book [Igielski 2008: 50]. The Guru Granth Sahib is the Holy Book in which the sacred hymns and texts contained are treated with reverence and considered to be the living eleventh guru. It has been kept until today in Amritsar at the Golden Temple - the most sacred place of the Sikhs [Cole, Sambhi 1987: 56].

In 1801, one of Sikh maharajas was able to establish a Sikh state, often referred to in literature as the Sikh Empire [Grewal 2008: 99]. Its core was an army made up of the Khalsa brotherhood. It is significant that in the Sikh Empire, the followers of the religion constituted only about $10 \%$ of the entire population. The remaining religions in the Sikh state were Islam, whose followers made up as many as $80 \%$, and Hinduism and other religions. In spite of this, the authorities of the Empire did not repress representatives of other faiths and there were no wars on religious grounds in the Sikh Empire [Duggal 1983: 63]. The Sikh state, despite the great political and military power at its disposal, did not survive the conflicts with the British, who were conquering ever larger territories. Due to the strong military traditions in the community, the Sikhs soon became one of the most important groups in the colonial army of British India. The Sikhs contributed to the suppression of the biggest uprising against colonial rule. The so-called Sepoy Mutiny broke out in 1857 and in a short time, encompassed almost all of British India. However, it ended with the defeat of the insurgents, thanks in part to the contribution of the Sikh soldiers to the operations of the British army [Kieniewicz 1985: 617]. The British rewarded the Sikhs' loyalty by giving them management over the gurdwaras, and in particular over the Amritsar Golden Temple complex.

In the history of the Sikhs, the colonial period is also known as a time of religious renewal of this community. The British treated Sikhism as one of the factions of Hinduism, which the followers of that religion strongly opposed. At that time, organizations such as Singh Sabha, Khalsa Diwans, Akali Dal and the Shiromani Gurdwara Parbandhak Committee were established, which worked to strengthen the cultural separateness of the Sikhs through, among others, education and management of temples and ceremonies performed in them. Organizations started to open their own schools, even universities, which led to the strengthening of the whole community. Members of the Sikh community continued to play an important role in the British Army, accounting for approximately $30 \%$ of its soldiers. This was not even half of the army, but it should be remembered that the Sikhs at that time accounted for only about $2 \%$ of the total population of British India. The followers of Guru Nanak also took an active part in the armed activities of the First and Second World Wars. In total, during the First World War, over 97,000 Sikhs fought in the British Army, while as many as 300,000 Sikhs fought during the Second World War [Shani 2008: 31]. The 
British promised volunteers a high salary and a peaceful life when they returned to India. However, the situation turned out to be completely different. After leaving the service on the fronts, such as those in Europe, the Sikhs did not receive the salaries promised by the British - this included the pensions for veterans who were often no longer able to work after returning to the Punjab. This was one of the reasons why they joined the national liberation struggle waged in 1919 by Mahatma Gandhi against British colonizers, which ended in success and the creation of two new independent states: India and Pakistan.

\section{SITUATION OF THE SIKHS IN INDIA AFTER 1947}

When establishing the new borders of India and Pakistan in 1947, the decision was made to divide the Punjab. In India, a new state called Punjab was created from the eastern Punjab, while in the western areas of the Punjab, which was located in Pakistani territory, a province of the same name was established. As in other border areas, attempts were made to determine the border in accordance with the religious beliefs of the inhabitants of these areas. It was not possible for all Muslims to be on the Pakistan side, or for all Hindus and Sikhs on the side of India. Thousands of families began their journey to their "proper" countries because they were afraid of pogroms. It was one of the biggest migrations in history. There are big differences in the data provided by different centers. However, it is estimated that about 5.5 million people moved from the Indian Punjab to Pakistan - mostly Muslims, while about 4.5 million Hindus and Sikhs moved from the Western Punjab to India [Singh 2008: 31]. The entire population of the Punjab included about $61 \%$ of Muslims, $26 \%$ of Hindus and $13 \%$ of Sikhs [Chima 2010: 29]. During the migration, there were mass attacks on travelers with all their belongings in these areas, resulting in the loss of hundreds of thousands of lives.

As a result of the resettlement after independence, the number of Sikhs in the population of the Indian Punjab changed significantly. Before the division, the followers of Guru Nanak accounted for about $12-15 \%$ of the total population in the area. After the division and the massive scale migration, they accounted for about $33 \%$ of the total population in the Indian Punjab. Following the establishment of the Indian state, the organization Akali Dal, which became the most important Sikh political party, began working to grant special rights to the Sikhs and to create a state in which members of this religious group would constitute the majority of the population. The first Indian prime minister, Jawaharlal Nehru, did not want to make any further divisions and was afraid of Sikh separatist tendencies, did not agree on the grounds that India was supposed to be a country unrelated to any religion [Dębnicki 2000: $160-161]$. The ratio of Hindus to Sikhs was also very important in this period. Many devotees of Hinduism treated Sikhism as a part of their religion, and attempted to persuade the devotees of Guru Nanak to return to their true roots. As a result, the Sikhs felt the need to mark their religious identity. The radicalization of Sikhs' attitudes 
was particularly strongly influenced by the provision in the Constitution of India of 1950, which defined Sikhism, together with Jainism and Buddhism, as one of the trends of Hinduism. Despite protests from the Sikh community, the constitution with such a provision was passed. In opposition to this open discrimination, members of Akali Dal, who were members of the Constitutional Assembly, refused to sign the new Indian constitution. There were mass protests in the Punjab; however, Indian authorities did not change the provision concerning Sikhism [Shani 2008: 43].

In the 1950s, the Akali Dal party, seeing that the assumptions of secularism, which were the basis of the newly formed Indian state, would not allow the creation of a Sikh-only state, decided to achieve their goal in a different way. During this time, a process of reorganization of some states had begun in India, based on language criteria. Although Prime Minister Jawaharlal Nehru, reluctant to face further divisions, did not agree with this proposal, in the end the government agreed to the separation of some territories. As the majority of Sikhs used the Punjabi language, Akali Dal started to fight for the creation of a separate state in which the majority of the population would use the language. Prime Minister Nehru, seeing the determination of the followers of this religion, did not want to agree to such a solution. In the name of the idea of Punjabi Suba, i.e. a state in which Punjabi would be the main language, there were mass demonstrations and protests in the Punjab. Hindus living in the Punjab opposed Akali Dal's proposal. Conflicts and tensions became more frequent in the territory of the state [Shani 2008: 45]. Increasingly, protests ended in street fights. About 60,000 members of Akali Dal were arrested during the protest and riots at the time [Chima 2010: 29]. The proposal put forward in 1956 by Jawaharlal Nehru was to create zones within the Punjab, where the main language was Punjabi (among others, the decision was made to introduce it to schools as a primary language). Akali Dal accepted the central government's compromise proposal and the situation in the Punjab seemed to have been under control. However, it was then that Hindu activists took the floor, who, with the founding of the Save Hindi movement, protested against the decisions of the central government and Akali Dal. This once again aroused radical moods among the Sikhs [Grewal 2008: 188-197]. The strengthening of the divisions between Sikhs and Hindus, who until recently were on the same side of the barricade in the fight against Muslims, was of great concern to the authorities in Delhi. They were afraid of the escalation of violence in the Punjab, whose inhabitants had not yet shaken off their memories of the tragic events of 1947.

The death of the first Indian prime minister, Jawaharlal Nehru, in 1964, had a major impact on the development of the situation in the Punjab. His successor, Lal Bahadur Shastri, took a different stance in the Sikh case. In 1966, the Shastri government decided to accept the Akali Dal postulates and to divide the Punjab on the basis of language criteria [Singh 2008: 32-33]. However, the creation of a state with a majority of Punjabi speakers did not take place with the participation of the second prime minister of independent India. He died in 1966, during peace negotiations with the president of Pakistan, Ayub Khan, in Tashkent. His direct successor, 
Indira Gandhi, like her father Jawaharlal Nehru, was against the division of the Punjab and the creation of a new Sikh state. The death of Shastri and the postponement of the decision by Indira Gandhi once again led to radicalization among Sikh society, and mass protests and demonstrations started in the Punjab territory. At the time, a special committee published an approved plan for a "new Punjab", which included the separation of areas where Hindi was the main language spoken. A new state called Haryana was created in the separated areas. In addition, a part of the area of the Punjab, where the Pahari language of the Himalayas was spoken, was annexed to the existing state of Himachal Pradesh [Singh 2008: 32-33]. One of the reasons for the central government's decision was the fact that the Sikhs, who at the time were a very strong element of the Indian army, contributed significantly to the victory in the war with Pakistan in 1965 [Cheema 2006: 73].

Thus, on 1 November 1966, for the first time in their history, the Sikhs obtained a territory in which they constituted the majority of the population. This was not even the case during the Sikh Empire in the $19^{\text {th }}$ century, when the Sikhs made up only about $10 \%$ of the total population of the Empire. In the new state, which mainly used the Punjabi language, the Sikhs accounted for $60.22 \%$ of the population, while the Hindus accounted for $37.54 \%$. This was undoubtedly a very great success for the Sikh community, although it was stressed in the Punjab that not all of Akali Dal's demands had been met (among others, a few areas where the Punjabi language was spoken were not included in the new Punjab) [Chima 2010: 32]. In addition, the idea of creating Khalistān, the sovereign state of the Sikhs, continued to emerge among the Sikhs.

However, the division of the Punjab in 1966 was defective from the very beginning and became the source of another conflict between the Sikhs and the central government. Indeed, the Indian authorities decided to establish the city of Chandigarh as the capital of both the new Punjab and the new state of Haryana. It was left as a union territory over which the central government exercised direct authority. The city of Chandigarh was desirable due to its modernist character. The establishment of Chandigarh as the capital of both the Punjab and Haryana met with great opposition from the societies of both states. In particular, in the Punjab, the struggle for Chandigarh was supported very strongly by organizations bringing together the Sikh community. Since India regained its independence, the Shiromani Gurdwara Parbandhak Committee (SGPC) had been gaining an increasingly strong position. Over the years, it started to play a major role on the political scene in the Punjab, despite its non-governmental nature. This organization became known as the "mini-parliament of the Sikhs". It was undoubtedly the largest and most important non-governmental bureaucratic institution in the Punjab. Members of Akali Dal very often sat on the SGPC, which shows that in the Sikh state, religious, cultural and political elements were constantly intertwined [Chima 2010: 24-25]. As part of the fight for Chandigarh, meetings, protests and manifestations were organized, in which millions of people were involved. Delhi received increasingly alarming signals from the Sikh state. As a result of negotiations, Indira Gandhi, wishing to stop the radicalization of the Sikhs in the Punjab, announced on 
26 January 1970 the decision to award Chandigarh to the Punjab as the sole capital. However, the actual handover of Chandigarh never took place [Grewal 2008: 199-209].

The 1960s in India were a period called the Green Revolution, which was initiated by Indira Gandhi. Crop yields in many Indian states increased thanks to government investments. However, nowhere was the development of agriculture and infrastructure as dynamic as in the Punjab. The improvement of the operation of the largest farms allowed for the enrichment of the better-situated part of the Punjab community. Smaller farmers became less and less competitive on the market, which resulted in their farms going into decline. This led to a significant stratification of the Punjab population. Social inequality once again led to radicalization in the Punjab.

After the declaration of the state of emergency in 1975, due to the political situation in the country, the Punjab opposed the actions of the central government. Akali Dal formed a social movement called Save Democracy. Again, protests and demonstrations, similar to those of colonial times, were held in the Punjab, and the fight to create a new state for those who spoke the Punjabi language was renewed. The Sikh resistance movement quickly spread from the Punjab to almost all of India [Chima 2008: 33]. There were mass arrests of persons participating in the activities of Save Democracy, which only strengthened the power of the protests. Until the lifting of the state of emergency and the holding of new elections, about 40,000 members of Akali Dal were arrested [Grewal 2008: 214].

After the defeat of the National Congress in the elections of 1977, the right-wing Janata Party took over the power in the country. At the state level, a coalition of Akali Dal and Janata Party won the elections in the Punjab. The social and economic problems of the population in the Punjab that followed the Green Revolution led to the radicalization of a large part of society. Akali Dal, taking advantage of the mood of dissatisfaction among the Sikhs, began to call upon them to demand justice in the name of religion [Jetly 2008: 66-67]. Increasing fundamentalism in society led, among other things, to the tragedy in Amritsar in 1978, during which the Sikhs attacked a group of Nirankari - followers of a religious movement originating from Sikhism, who believed in the existence of a living Guru, instead of the Holy Book. As a result of the fighting, 13 members of Akali Dal and 6 Nirankari died. Researchers refer to this as the beginning of Sikh terrorism, which led to Operation Blue Star, carried out by the Indian army in Amritsar in 1984 [Paroha 1993: 239-240].

\section{DEVELOPMENT OF SIKH FUNDAMENTALISM}

After the National Congress returned to power in 1980, the situation in the Punjab became increasingly tense. Economic and social problems, which were transferred by Akali Dal's rhetoric to religious ground, strengthened fundamentalism and, consequently, xenophobic sentiments among Sikhs. At that time, the ruling Akali Dal party was divided into many factions without an unequivocal leader for the entire organization. 
Other Sikh organizations continued to play a very important role. In one of them, Damdami Taksal, founded by the fifth guru of the educational organization, Jarnail Singh Bhindranwale, began to play an increasingly important role. At the end of the 1970s, he began to travel around the Punjab and called on the Sikhs to renew their religion. He persuaded his fellow believers to follow the path of the guru. He paid particular attention to the recommendations of the fifth guru, Gobind Singh, who introduced the "Five K" rule, including the obligation to wear a short dagger. However, Bhindranwale convinced people to also equip themselves with newer weapons, such as rifles or pistols. He was a very charismatic speaker, with a unique ability to quote texts from the Holy Book, and very quickly won the hearts of members of Sikh society. He formed his own political party, Dal Khalsa. The National Congress decided to take advantage of Bhindranwale and to support him, taking part of the Sikh electorate away from Akali Dal, thus securing his victory in the next state elections in the Punjab. However, Bhindranwale eventually did not decide to permanently support the Congress, while the rhetoric of Dal Khalsa became increasingly radical and directed against the central government [Paroha 1993: 238-239].

In 1981, an event took place that was important for the development of Sikh separatism. In March of that year, a Sikh immigrant living in the United States, Ganga Singh Dhillon, gave a speech in Chandigarh, in which he called the Sikh community a nation that was ready to proclaim an independent state in the Punjab. Dhillon's words became a kind of turning point for the Sikhs, who from that moment on, started to speak openly about the idea of creating Khalistān and about their own identity [Oberoi 1987: 39]. The determination of the Sikh diaspora, the financing of fundamentalism in the country and the constant proclamation of Khalistān idea by many emigrants from the country contributed significantly to the successes of Bhindranwale's followers in the Punjab [Tatla 2014: 499]. In 1982, the President of the World Sikh Convention, Harchand Singh Longowal, recommended that Akali Dal, together with Bhindranwale, begin planning a real dharmyudh, i.e. a just war for the creation of Khalistān [Grewal 2008: 219].

Jarnail Singh Bhindranwale began to speak openly about the fact that the Sikhs were a second-class nation in India and slaves who must free themselves from the yoke of power in Delhi. He urged everyone to fight [Iwanek, Burakowski 2013: 326]. High popularity combined with discontent and increased fundamentalism led to a large part of the Sikhs supporting Bhindranwale. The support of young people, often university graduates, was particularly strong, as they were unable to find employment in the Pun$\mathrm{jab}$ and succumbed to religious extremism, thus finding a purpose in their lives. Bhindranwale was actively supported by the All-India Sikh Student Federation, numbering 300,000 members in 1981, who became the most loyal activists of the Bhindranwale movement [Kiss 2009: 12]. With time, their activities increasingly frequently took the form of bloody attacks on people of other faiths. Bhindranwale gathered around him a group of the most radical followers of Sikhism, who were ready to do anything in the name of religion. A large part of the Sikh community in the Punjab supported their 
activities. Radicalization of attitudes among the Sikhs led to an increase in radicalism among Hindus as a result. Attacks on the Sikhs took place both in the Punjab, as well as Rajasthan and Haryana [Singh 1988: 750-751]. Bhindranwale organized a strong terrorist group of several hundred, which terrorized the whole state, supported by many of its inhabitants. Every day there were attacks on Hindus, arson of entire Hindu villages or various acts of vandalism. The "killer troops" created by Bhindranwale attacked buses on the roads, killing all those who did not wear a turban. Terror reigned throughout the Punjab and the state authorities and police were unable to deal with it.

In 1982, Jarnail Singh Bhindranwale annexed the entire area of the Golden Temple, where he settled with a group of several hundred terrorists. He was afraid that in any other place in the Punjab, he would be arrested by the state authorities. In addition, the establishment of a holy place as his home was intended to strengthen his authority among his fellow worshippers. From there, he commanded terrorist attacks throughout the state. The terrorist leader did not refrain from killing his fellow worshippers if they opposed his methods of fighting for the freedom of the Sikhs. There were also attacks on police officers working in the Punjab [Jetly 2008: 67]. In the Punjab, the Sikhs accounted for as much as $65 \%$ of all policemen. Therefore, they were the guardians of law and order, which meant that they were often the focus of Bhindranwale's fundamentalist activities [Kiss 2009: 11]. A great deal of publicity throughout India was given to the murder of the Deputy Inspector General in Amritsar, who was shot dead after praying at the Golden Temple [Grewal 2008: 219-242]. In addition to the significant contribution of the Sikh diaspora to the financing of terrorists, the government of Pakistan has also contributed to their activities. Authorities in Islamabad, like members of the diaspora, supported Bhindranwale's terrorists by providing them with funding. In addition, special training camps for Bhindranwale's terrorists were organized in the border areas on the Pakistani side [Grewal: 2008: 245].

Both open and secret meetings between representatives of Akali Dal and members of the government continued to take place in order to find a solution to the situation in the Punjab. However, despite the compromises reached on some issues, the two parties were not able to reach an unambiguous agreement. The last, fruitless meeting of the Indian prime minister with representatives of the Sikhs took place in May 1984 [Singh 1988: 752-755].

For a very long time, the central government refrained from intervening directly in the Punjab. It was feared that attempts to control the situation in the Sikh state by force would lead to even more radicalization of the followers of Guru Nanak's religion. In 1980, the National Security Act was adopted, which partially restricted constitutional freedoms and allowed uniformed services to arrest and imprison people threatening the security of the state for up to two years. In 1982 and 1983, further legal acts were introduced, among others, significantly extending the powers of the police. However, these efforts did not have the desired effect and the bloody attacks by the Bhindranwale terrorists continued. In the face of such a large scale of violence, Prime Minister Indira Gandhi agreed to conduct counter-terrorism operations on an 
unprecedented scale in India. On 3 June 1984, with the support of tanks, artillery and rocket grenade launchers, the army surrounded the sacred area of the Sikhs - the Golden Temple complex. All roads leading to Amritsar were closed, journalists were ordered to leave the city centre and a curfew was put in place. Many soldiers were afraid of carrying out such a great profanation of the sacred land of the followers of Guru Nanak, on which they did not even walk while wearing shoes. However, the fact that Bhindranwale organized the command post for terrorist actions in the whole territory of the Punjab in the complex of the Golden Temple left the Indian military with no choice. The situation was also logistically difficult, because it was not clear what kind of weapons the terrorists had, how many there were and where exactly they were located. Terrorists were well prepared to defend the holy place. Akali Takht - one of the buildings in the temple complex - was very carefully fortified. The terrorists even had anti-tank weapons, which were directed against the tanks of the Indian army. The day chosen for the operation was not without significance. The $5^{\text {th }}$ of June is a Sikh holiday, commemorating Guru Arjan becoming the first Sikh to suffer martyrdom for his faith. Such an important ceremony was attended by thousands of Guru Nanak's followers, who came to the holy site in Amritsar from all over the country [Hassner 2009: 175]. The battle between the Indian army and Sikh terrorists lasted two days. Several hundred terrorists hiding in the temple complex and thousands of innocent pilgrims were killed during the operation. Many buildings around the Golden Temple were ruined. Jarnail Singh Bhindranwale, who was almost immediately declared a martyr and a saint by many Sikhs, was among the dead on the terrorist side.

During this time, Operation Woodrose was conducted throughout the Punjab and in some parts of India, during which the military took control of the gurdwaras and thousands of Sikhs were arrested, including the leaders of major Sikh organizations and political parties. The action was aimed at preventing a violent reaction to the Operation Blue Star. Despite the additional military operation, the Indian authorities were not able to fully control the mood of the community. Many Sikhs, who had not been previously involved in the fight for Khalistān, became radicalized in the face of such an open profanation of their sacred place. During this time, about 2,500 Sikh soldiers left the Indian army throughout the country [Grewal 2008: 228]. In a retaliatory act for the military operation in the Golden Temple, two Sikhs murdered Prime Minister Indira Gandhi in front of her home on 31 October 1984 [Kalmar 1989: 281].

The death of Indira Gandhi at the hands of Sikh fanatics was very important for the later history of the Punjab. The news of the murder of the beloved Mother India immediately spread across the country. Millions of people came to Delhi to say goodbye to Indira Gandhi. Mass pogroms against the Sikh population began throughout India. The events in the capital city took a particularly drastic course, with the whole city being searched to find the hiding Sikhs. From infants to old men, the followers of Guru Nanak who were caught were murdered with particular cruelty. Not only did the police and the army not stop the crowds, but they also often joined in the torture 
and murder of Sikhs. It was three days after the assassination of Indira Gandhi until troops were sent into the streets of Delhi. The decision was made by the son of the late prime minister, Rajiv Gandhi, who was spontaneously appointed by the Indian President as the next prime minister without any legal grounds. By that time, about three thousand Sikhs had died in the streets of the city [Singh 1988: 775].

In the aftermath of mass Sikh pogroms throughout India, followers of the persecuted religion began to flee to the Punjab in search of shelter. Every day, hundreds of thousands of Guru Nanak's followers arrived in the Sikh state. The survivors of the Sikh pogroms shared their stories with the people who lived in the state, which led to even greater radicalization among the Punjabi community. For this reason, Hindu families began to flee from the Punjab at that time, also becoming victims of pogroms. It is estimated that about a thousand Hindu families fled from the Punjab within a few months. From all over India, about 26,000 Sikhs came to seek shelter in the Punjab. The migration in 1984 influenced the demographic situation of the Punjab. The percentage of Sikhs in the total population of the Punjab increased, which, combined with the radical mood of the community, led to an even stronger conviction of the Sikhs in their right to self-determination in the area [Tatla 2014: 33].

\section{THE SITUATION OF THE SIKHS AFTER 1984}

The new Indian Prime Minister, Rajiv Gandhi, much like his mother and grandfather, faced the problem of calming down the radical mood among the Sikh community. He launched a series of political movements to ease the tensions between the Punjab and the central government. Among other things, he released the leaders of Akali Dal from prison and set up a special commission to investigate the events in Delhi following the death of Indira Gandhi. He also announced that Chandigarh would be declared the sole capital of the Punjab. However, the date of the event was postponed several times, which again led to an escalation of tension among the Sikhs and further terrorist actions in the Punjab. The mood in the Sikh state deteriorated once again [Jetly 2008: 68]. The 1985 terrorist attack on an Air India aircraft carried out by Sikh terrorists, during which all the passengers were killed as a result of the detonation of explosives, echoed worldwide. There was an ongoing counter-terrorist campaign carried out throughout the Punjab, but it did not bring about a marked improvement of the situation. Chaos and anarchy still reigned in the Punjab. It was not until 1992 that the central authorities declared victory over the Sikh separatists, although in practice, attacks and an anti-terrorist operation continued in the Punjab. It was important to stabilize the situation in the Punjab and weaken the separatist forces, and to gradually reduce their financing from Pakistan [Jetly 2008: 70-72]. The actions of the central government in relation to Sikhs after 1984 are another controversial issue in relations between Sikhs and central authorities. During the counter-terrorist operation, thousands of Sikhs suspected of terrorism were taken without explanation from their homes, to 
which they never returned again. Among other things, the subject of the dispute is the fact that entities operating within the framework of a government operation often did not admit to taking specific persons. In his book on the history of Sikhs, Mewa Singh states that from the beginning of anti-terrorist activities in the Punjab until 1995, about 30,000 to 60,000 Sikhs disappeared. The fate of most of them is still unknown, but reports from the human rights body of Akali Dal show that mass cremations took place in the vicinity of Amritsar during that time [Singh 2010: 507].

Gradually, the situation in the Punjab began to stabilize. In the following years, the political scene of the Sikh state saw an exchange of power between Akali Dal and the National Congress. The economic development of the state in the following years contributed to the reduction of radical sentiment in the Sikh community. However, demonstrations for the establishment of Khalistān continue to be held by Sikhs around the world, but they are peaceful in nature. Many of them are organized outside of India.

\section{CONCLUSIONS}

The history of the Sikhs shows how a community that has peace and helps others in the face of danger at its core can become radical and, supported by the interests of external actors, become the nucleus of unrest and conflict throughout the country. Among the causes of the growing radical tendencies in the Sikh community, several factors can be distinguished. One of them is the need to defend their fellow believers against attacks from the followers of another religion, as happened during the division of the sub-continent in 1947. The desire to have one's own place in a newly established country is also important. Another issue is the assistance given to the radicals by external actors, including Pakistan, which was in competition with India, and the wealthy Sikh diaspora. Furthermore, the identification of Sikhism with the most popular religious trend in India, i.e. Hinduism, additionally influenced the need for members of this religion to prove their separate religious identity. The radicalization of the Sikh community was also caused by the socio-economic problems and increasing social stratification in the Punjab. Undoubtedly, one of the most important elements in the Sikh situation were decisions taken by the Indian government. The actions taken with regard to the Sikh community in the subsequent years cannot be unequivocally assessed positively. Analyzing the history of the Punjab, it can be clearly seen that promises made by successive politicians, which were then not fulfilled, were one of the most important factors in the growth of radical tendencies in the community.

At present, Sikhs are perceived positively in India. Organizations such as the Shiromani Gurdwara Parbandhak Committee continue to play an important role in the Sikh community. As in previous years, the Sikhs are still an important part of the Indian military, often holding high ranks in the army. Many researchers describe the Sikh community as the strongest religious minority in India [Cheema 2006: 67]. The best evidence of the change in the perception of the Sikh minority by other Indian 
citizens is the fact that in 2004, Manmohan Singh was sworn in as the fourteenth Indian prime minister, becoming the first practicing Sikh Indian prime minister, and held this post until May 2014.

\section{BIBLIOGRAPHY}

Cheema, K. 2006. Sikh Communal Consciousness and State Violence in India, "Pakistan Horizon", vol. 59 (3).

Chima, J.S. 2010. The Sikh Separatist Insurgency in India: Political Leadership and Ethnonationalist Movements, Sage Publications, New Delhi.

Cole, W.O., Sambhi, P.S. 1987. Sikhowie. Wiara i życie, Wydawnictwo Łódzkie, Łódź.

Dębnicki, K. 2000. Konflikt i przemoc w systemie politycznym niepodległych Indii, Wydawnictwo Akademickie Dialog, Warszawa.

Duggal, K.S. 1983. Ranjit Singh: A Secular Sikh Sovereign, Abhinav Publications, Dusenbery, V.A.

Grewal, J.S. 2008. The Sikhs of the Punjab, [in:] The New Cambridge History of India, Vol. II, Part 3, B. Stein (ed.), Cambridge University Press, Cambridge.

Hassner, R.E. 2009. War on Sacred Grounds, Cornell University Press, New York.

Igielski, Z. 2008. Sikhizm, WAM, Kraków.

Iwanek, K.A., Burakowski, A. 2013. Indie. Od kolonii do mocarstwa 1857-2013, Wydawnictwo Naukowe PWN, Warszawa.

Jetly, R. 2008. The Khalistan Movement in India. The Interplay of Politics and State Power, "International Review of Modern Sociology", vol. 34 (1).

Kalmar, G. 1989. Indira Gandhi, Wydawnictwo Książka i Wiedza, Warszawa.

Kieniewicz, J. 1985. Historia Indii, Zakład Narodowy im. Ossolińskich, Wrocław.

Kiss, P.A. 2009. Counterinsurgency in the Punjab - A Lesson for Europe, http://www.researchgate.net/publication/215862592_Counterinsurgency_in the Punjab_A_Lesson_for_Europe (access: 25.05.2016).

Oberoi, H.S. 1987. From Punjab to "Khalistan": Territoriality and Metacommentary, "Pacific Affairs", vol. 60 (1).

Paroha, U. 1993. Terrorism in Punjab, Origins and Dimensions, “The Indian Journal of Political Science", vol. 54 (2).

Shani, G. 2008. Sikh Nationalism and Identity in a Global Age, Routledge, New York.

Singh, G. 1988. A History of the Sikh People, World Book Centre, New Delhi.

Singh, M. 2010. Religion and History of the Sikhs 1469-2010, Singh Brothers, Amritsar.

Singh, P. 2008. Federalism, Nationalism and Development. India and the Punjab Economy, Routledge, New York.

Tatla, D.S. 2014. The Sikh Diaspora, [in:] The Oxford Handbook of Sikh Studies, P. Singh, L.E. Fenech (eds.), Oxford University Press, Oxford.

\section{BIOGRAPHY}

Magdalena Cyran, MA, she is a doctoral student at the Jagiellonian University in Kraków, Faculty of International and Political Studies. E-mail: cyran.mag@gmail.com 